\title{
Solusi Madrasah dalam Menghadapi Problematika Ketidakhadiran Guru dalam Kelas
}

\author{
Moh. Hafidurrahman ${ }^{1}$ \\ ${ }^{1}$ IAI AI-Khairat Pamekasan, Indonesia \\ ${ }^{1}$ hafidzbarizi@gmail.com
}

\begin{abstract}
Abstrak
Tulisan ini bertujuan untuk mencari solusi serta mengetahui alasan-alasan kertidakhadiran guru kedalam kelas, upaya yang dilakukan madrasah untuk meminimalisir ketidakhadiran guru. Terdapat beberapa dampak yang dirasakan oleh siswa ketika guru tidak hadir ke dalam kelas, siswa dirugikan dan kecewa, hal ini dapat menurunkan minta dan motivasi belajar mereka. Selain itu hal ini berpengaruh terhadap kedisiplinan siswa. Metode yang diagunakan dalam jurnal kali ini adalah kajian teoritis yang diambil dari pendapat para pakar pendidikan. Dari pendapat tersebut lalu dianalisis secara mendalam. Ketidak hadiran juga karena malas untuk mengajar, ini juga bisa menjadi benih inkonsistensi bagi guru yang biasanya rajin. Disini kami mencoba mencari solusi dari permasalahan tersebut (problem solving), bahwa madrasah harus berani bertindak supaya mdarsah betul-betul efektiif. misalnya memberikan reward bagi guru yang aktif and punisment bagi guru yang jarang hadir ke madrasah, karena dari beberapa masalah yang ada di lembaga lain adanya pengaruh positif terhadapa kehadiran guru ketika ada penerapan Reward dan Punishment terhadap kedisiplinan guru yang hadir didalam kelas pada kegiatan belajar mengajar.
\end{abstract}

Kata Kunci: disiplin, ketidakhadiran, problematika madrasah

\section{Pendahuluan}

Madrasah yang maju selalu ditopang dengan tingkat kehadiran guru yang tinggi, karena kehadiran guru kedalam kelas merupakan sebuah tanda bahwa madrasah atau madrasah tersebut sangat aktif dan efektif dalam menjalankan proses belajar mengajar. Begitupun sebaliknya jika tingkat kehadiran guru di lemabaga madrasah sangat kecil, maka bisa dipastikan ada yang yang salah dalam manajemen madrasah tersebut. Sebenarnya masalah ketidakhadiran guru kedalam kelas meruapakan problema lama, tetapi penulis sangat tertarik sekali untuk mengupas seputar masalah ini, karena penulis termasuk bagian dari pengelola di madrasah tersebut yang konsen terhadap aktivitas guru.

Kelas yang tidak ada gurungnya itu bagaikan 'sunnatullah / hukum alam' di madrasah / sekolah. Dari itu madrasah harus menyiapkan jurus jitu untuk mengisi jam yang ditinggalkan oleh guru di madrasah. Kita mungkin tidak berharap begitu tapi kenyataan berbanding terbalik dengan harapan. madrasah tidak punya peraturan yang jelas tentang bagaimana menyiasati kelas yang dtingglakn oleh guru. Kalau pun ada peraturan tersebut biasanya hanya berupa kesepakatan sementara yang tidak dijadikan pedoman tertulis secara resmi. Jarang ada madrasah yang punya kebijakan semacam itu dan ini adalah kasus yang sangat lumrah terjadi. Apalagi guru piketnya tidak sepadan keilmuannya dengan kemampuan guru 
pengampu mapel yang asli, pastinya guru piket tidak mengisi materi pelajaran yang ditinggal guru sesuai dengan mata pelajaran dan ditinggalkan oleh guru, baik yang malas atau yang berhalangan. Senada dengan apa yang dikatakan oleh Ali Ridho dalam Jurnal Fikrotuna, bahwa syarat menjadi guru mempunyai konskwensi untuk mempunyai kemampuan yang memadai dengan metodologi penyampaian materi dengan baik (Ali Ridho, 2017).

Guru merupakan seorang educator dalam edukasi yang seharusnya menjadi uswah suri tauladan yang baik dan memberikan value caharacter building yang bagus kepada siswasiswinya, Guru bukan hanya mampu men-transformsi keilmuan saja kepada murid, tapi juga mentransfer value atau karakter yang baik (transferring the good). Sebelum guru menerapakan kedisiplinan kepada siswa maka sebaiknya guru terlebih dahulu mendisiplinkan dirinya, jadi guru perlu mulai dari dire sendiri sepadan dengan semboyan pekan ngaji 5 "think Global acts local" atau ibda' binafsik artinya jika guru tidak senang melihat siswanya datang terlambat ke madrasah maka guru harus terlebih dahulu harus introspeksi diri dan bermuhasabah.

Pada lingkungan madarasah fenomena terlambat datang memiliki kisah unik sekaligus ironis. Bagi sebagian orang, khususnya siswa terlambat datang ke madrasah merupakan pengalaman yang tidak enak. Sebab, terkadang walaupun siswa memiliki alasan (reason) yang jelas mengapa datang ter-lambat, tetap saja mendapatkan punishment dari guru BK atau petugas kedisiplinan di madrasah. Berbeda hal-nya dengan guru, kadangkadang guru mendapatkan perlakuan yang berbeda. Jika yang terlambat adalah guru, siswa sering sekali harus memaklumi and menerima keterlambatan guru tersebut, apalagi kalau guru tersebut termasuk orang yang berpengaruh di madrasah tersebut, maka yang pasti tidak akan ada sanksi bagi guru yang dimaksud apabila terlambat datang ke madrasah.

Salah satu masalah yang menjadi problematika besar di madrasah yang di Indonesia ini adalah masih tingginya tingkat ketidakhadiran guru kedalam kelas. Banyak kelas yang kosong karena ditinggal oleh gurunya entah karena sakit, meeting ini dan meeting itu, ada acara keluarga, atau sedang ada jam mengajar di madrasah lain, ikut acara MGMP, ikut arisan, masih belanja di pasar, melayat tetangga yang sakit, atau sekedar malas saja masuk ke kelas. Ini adalah Daftar alasan sangat variatif dari guru. Dan seperti kita kita ketahui bahwa semua pihak madrasah nampaknya mafhum saja dengan situasi ini. Walaupun dibalik itu sebenarnya mereka mendongol kenapa selalu izin.

Atas beberapa fakta diatas maka penulis sangat tertarik mengupas dan membahas kajian masalah ketidakhadiran guru dengan judul "Solusi Madrasah dalam Menghadapi Problematika Ketidakhadiran Guru Kedalam Kelas" dengan harapan nanti akan dijadikan sebagai pedoman bagi madrasah tersebut dalam menghadapi masalah ini.

Dalam Kamus Besar Bahasa Indonesia istilah guru yang tidak hadir memberikan makna bahwa "ketidakhadiran" merupakan kata yang sama dengan "absensi", yang berarti suatu kondisi dimana guru tidak mengajara langsung di dalam kelas atau absen. Kata yang sepadan adalah "mangkir" yang berarti tidak datang ke madrasah atau ke tempat diamana dia bekerja karena sakit atau alasan yang tidak diketahui (Syaikhu, Akhmadi dan Suryadarma Daniel. 2004). 


\section{Kedisiplinan Kinerja Guru}

Seperti yang ditulis oleh Menurut Mangkunegara (2013), kedisiplinan dalam bekerja di sebuah lembaga dapat memperteguh prinsip-prinpsi berorganisasi yang palaksanaannya dilakukan dengan tekun. Terkadang, keadaan mental dan psikis guru sedang sangat tergganggu sehingga berdampak terhadap terjadinya penurunan motivasi dan gairah mengajar. Oleh karena itu, kedisiplinan sangat diperlukan dalam meningkatkan motivasi siswa. Dalam berorganisasi, masih banyak guru yang terlambat ketika masuk kelas, mengabaikan aturan tepat waktu yang ditetapkan oleh lembaga, tidak mengikuti juknis yang telah ditentukam. Disiplin dapat diartikan menghormati, memberikan respek, mematuhi, dan taat terhadap peraturan beserta norma yang berlaku di madrasah. Dalam arti yang lebih besar disiplin adalah sebuah manajemen dalam berorganisasi untuk memotivasi anggotanya untuk mengikuti segala peraturan tersebut.

Peran guru yang sangat vital dalam mensukseskan pendidikan tertuang dalam apa yang disampaikan oleh Fauzan (2019) nbahwa Kewajiban menuntut ilmu tidak dibatasi oleh ruang gerak dan waktu, karena kewajiban menuntut ilmu dalam Islam berlangsung sejak manusia lahir hingga mati, sebagaimana hadits yang artinya tuntutlah ilmu sejak lahir hingga ke liang lahad (meninggal). Pressure dalam mencari knowledge / ilmu yang sumber asalnya dari hadits ini memberikan pemahaman bahwa guru juga berkewajiban melanjutkan titah belajar sepanjang hayat yang disampaikan oleh Nabi Muhammad SAW.

Keberhasilan suatu perusahaan dapat dilihat dari kedisiplinan para anggotanya dalam mencapai tujuan tujuan oraganisasi (Hasibun, S. M. 2015). Disiplin berfungsi sangat penting di madrasah karena semakin baik kedisiplinan gurunya maka semakin tinggi prestasi murid murid yang diraihnya. Sebaliknya, tanpa kedisiplinan, maka sulit bagi lembaga seperti madrasah meraih hasil yang maksimal dalam memperjuangkan pendidikan yang lebih baik. Kedisiplinan harus diterapkan dalam madrasah karena akan berdampak terhadap kinerja pengelola, dan menjadi penentu succesfull dari lembaga pendidikan.

Kedisiplinan Guru juga didukung faktor motivasi oleh karenanya Moh. Dannur menyatakan bahwa Supaya peserta didik smerasa enang, nyaman serta bergairah dalam belajar, maka guru harus berusaha termotivasi untuk memvasilitasi semuanya. motivasi semacam ini harus terpatri pada diri seorang guru (Moh. Dannur, 2017).

Sinungang (2008) menyatakan dalam bukunya bahwa disiplin terpancar dari pola kerja dengan spesifikasi sebagai berikut. (1) Pertama dia mempunyai hasrat (eager) yang power untuk melaksanakan tugas sepenuhnya, hal-hal yang mempunyai nilai normatif, etika, dan kaidah yang berlaku di dalam organisasi, (2) mempunyai perilaku yang dapat dikendalikan (can be handled), dan (3) mempunyai sifat ketaatan (obeying).

Dalam upaya penerapan kehadiran dikelas yang efektif dalam proses pembelajaran (learning process) bisa ditempuh dengan beberapa terobosan diantaranya sebagai berikut ini: a) madrasah mempunyai system pengendali kehadiran guru yang dijalankan secara proporsional, (b) setiap kali ada meeting dengan guru maka perlu diinfokan tentang frekuensi dan fluktuasi kehadiran guru mulai yang tertinggi hingga yang paling rendah. Selain itu juga perlu diimplementasikan system reward dan punishment untuk meningkatkan kedisiplinn guru dalam kehadiran teaching activity dikelas. (c) pada awal permulaan semester madrasah yang diwakili kepala madrasah membuat MoU bersama guru tentang kode etik techers descipline (d) menajdikan disiplin sebagai bentuk keteladanan dalam 
aktifitas sehari hari mulai dari headmaster madrasah hingga staff madrasah (e) memberikan obligasi guru untuk aktif mencatat buku absensi yang telah disediakan di dalam kelas jika aktiftas nya berupa luring, dan aktif mengisi e-learning madrasah jika aktifitas madrasah berjalan secaran daring/online, (f) mempersempit ruang gerak guru untuk bisa izin keluar dari kelas terlbih dahulu sebelum bel tanda berakhir jam pelajaran (Johanes Purwanto, 2017).

Beda halnya dengan apa yang disampaikan oleh Bafadhal Ibrahm dalam bukunya, diaman dia menyebutkan bahwa ada beberapa faktor guna menciptakan iklim menagajar yang kundusif di dalam kelas: 1) guru sendiri yang ke 2 adalah interaksi dengan orang lain dan lingkunagn sekitar. Selain itu beliau juga menjustifikasi bahwa professional teacher adalah guru yang mampu memanje dirinya dalam mengemban tugas dan amanah sehari-hari. Disnilah Profesionalisasi guru akan menjadi sebuah proses yang merubah wujud ketidaktahuan menjadi tau, serta mengubah dari ketidakmatangan menjadi lebih siap lahir batin (Bafadal Ibrahim. 2004).

\section{Strategi Mengurangi Ketidakhadiran Guru}

Menurut Emmanuel Iriemi Ejere (2010), Ada beberap starategi yang dapat dilakukan oleh lembaga pendidikan dalam mengatasi keabsenan guru dalam kelas sebagaimana berikut:

\section{Penerapan peraturan dan regulasi}

Untuk memeriksa atau membendung tingginya tingkat ketidakhadiran di antara para guru, harus ada langkah-langkah prosedural yang ketat untuk meningkatkan penghalang ketidakhadiran dan membuatnya lebih mudah untuk melaporkan diri sendiri sakit atau mendapatkan izin untuk tidak bekerja. Dalam hal ini, kewajiban atau persyaratan untuk menunjukkan surat kesehatan dari rumah sakit pemerintah setelah satu hari absen harus diberlakukan.

\section{Menumbuhkan budaya yang tidak mentolerir ketidakhadiran yang berlebihan}

Dalam hal ini, catatan kehadiran harus disimpan secara religius untuk tujuan pelacakan kehadiran guru. Catatan kehadiran harus ditinjau ulang dengan setiap guru setiap semester sekolah atau lebih sering dengan mereka yang mengembangkan tren ketidakhadiran dengan tujuan untuk menahan kecenderungan yang tidak diinginkan.

\section{Dengan sengaja meningkatkan status ekonomi dan sosial guru}

Gaji guru dan penghargaan materi lainnya harus mencerminkan nilai fungsi pengajaran bagi masyarakat; dan sebaiknya dibandingkan dengan gaji yang dibayarkan dalam pekerjaan profesional lain yang membutuhkan kualifikasi yang serupa atau setara. Oleh karena itu, gaji guru dan insentif materi lainnya harus ditinjau ke atas secara signifikan agar tetap setara dengan apa yang dapat diperoleh dalam profesi yang sebanding.

\section{Penyediaan lingkungan kerja yang kondusif}

Guru membutuhkan suasana kerja yang lebih baik di dalam kelas. Sekolah dasar harus direhabilitasi dan direposisi agar kondusif untuk pengajaran dan pembelajaran yang efektif. Prasarana, sarana, dan perlengkapan yang memadai perlu disediakan di sekolah jika kita 
mengharapkan kehadiran guru meningkat. Selain itu, rasio guru-murid harus dikurangi menjadi maksimal 1:30 untuk mencegah kepadatan yang berlebihan di dalam kelas dan selanjutnya, stres pada guru.

\section{Penghargaan atas kehadiran}

Menurut Akyeampong, K. (2007) bahwa mengakui dan menghargai kehadiran akan mengirimkan pesan yang jelas dan kuat kepada staf pengajar bahwa kehadiran itu penting dan diperhatikan. Guru dengan catatan kehadiran yang baik harus diberi penghargaan dalam beberapa cara seperti melalui surat pujian atau bahkan penghargaan.

\section{Pemberdayaan guru}

Guru harus diberdayakan dengan mengadopsi pendekatan partisipatif untuk administrasi dan manajemen sekolah. Dalam hal ini, kebijakan dan program sekolah harus ditinjau untuk mengidentifikasi bagaimana guru dapat berpartisipasi dalam pengambilan keputusan tentang pekerjaan mereka.

\section{Membangun manajemen berbasis sekolah (MBS)}

Para kepala Madrasah serta komite berusaha membangun manajemen berbasis sekolah sehingga mendapatkan kontrol yang lebih besar sehubungan dengan disiplin pengajar mereka yang salah karena hal ini akan meningkatkan akuntabilitas dan kemungkinan mengurangi ketidakhadiran guru. Faktanya, para guru harus diberi tahu bahwa mereka berisiko mengalami pemutusan hubungan kerja karena ketidakhadiran yang berlebihan atau kebiasaan.

Mengembangkan program kesehatan Guru yang sehat cenderung tidak jatuh sakit atau melaporkan sakit, dan program kesehatan di tempat kerja dapat mendorong kesehatan yang baik. Tindakan pencegahan kesehatan berorientasi kerja seperti pemeriksaan medis rutin, penilaian kebugaran, latihan dan resep nutrisi dikaitkan dengan kesehatan karyawan yang lebih baik. Program kesehatan juga dapat mencakup tindakan untuk mengurangi stres; karena tindakan apa pun yang dilakukan untuk mengurangi stres pada gilirannya akan selalu mengurangi ketidakhadiran guru menurut Miller, R. (2012).

\section{Reward and punishment}

Pengawan didalam pengelolaan madrasah, biasanya tidak bisa berjalan sebagaiamana mestinya, terlebih lagi jika komitmen dan prinsip para guru sangat rendah. sehingga madrasah kemudian mengalamai kendala dalam upaya memajukan madrah. implementasi kedisiplinan guru untuk mengurangi guru yang tidak hadir dapat dilaksanakan dengan pemberian reward dan memberikan ancaman (reward and punishment). Keduaa hal ini akan menjadi sebuah motivasi yang mendorong seorang guru agar terus melkaukan perbaikan perbaikan sera aktif didalam mengajar di kelas sehingga mampu meningkatkan prestasi dan prestise para siswa di madrasah tersebut (Bambang Nugroho. 2006).

Rewards yaitu berupa pengahrgaan bisa saja hadiah, atau perangkingan penghargaan atau imbalan. Dalam teori pengelolaan, reward merupakan salah satu cara untuk memboosting motivasi guru. Sedangan pemberian punishmen merupakan ancaman yang hampir similar dengan sebuah konsekuensi bentuk anggung-jawab seorang guru karena tidak melakukan kewajiban dalam learning process. Cara cara seperti ini sudah tidak asing 
lagi dikenal dalam dunia Pendidikan. Dalam dunia pendidikan pun kedua ini kerap kali digunakan, tidak hanya dalam dunia kerja tetapi juga dalam education agency.

\section{Pendorong Ketidakhadiran Guru}

Banyak hal yang diketahui tentang kaaitan antara ketidak-hadiran guru, kebijakan/policy yang relevan, dan praktik manajemen. Orang akan menganggap, dengan melihat tingkat ketidakhadiran yang lebih besar dimana banyak guru yang izin/cuti. Guru juga cenderung lebih jarang absen jika mereka diminta untuk memberi tahu kepala sekolah tentang ketidakhadiran yang akan datang melalui telepon. guru bisa mendapatkan properity dari kebijakan/policy yang ditrepakan oleh madrasah dimana keseimbngan hak dan cuti itu berjalan dengan baik.

Tetapi kebijakan dan manajemen saja tidak menentukan perilaku ketidakhadiran Guru. Faktor tingkat individu dan sekolah juga penting. Guru perempuan cenderung lebih sering tidak hadir dibandingkan guru laki-laki, sebuah temuan yang konsisten di seluruh sektor pekerjaan dan terkait dengan tanggung jawab keluarga yang sangat gender. Guru yang jaraknya jauh itu lebih rentan terhadap cuaca buruk dan hambatan lain juga cenderung lebih sering absen dibandingkan guru dengan perjalanan yang lebih pendek. disini kami telah berhasil meresume empat reasoning dan penyebab teacher malas melakukan pembelajaran di Kelas, ini sangat familiar terjadi di lingkungan madrasah yaitu (1) Pemberian Honor kurang proporsional dan telat, (2) Faktor Internal (Pimpinan), (3) Kesenjangan diri, dan (4) Guru abal-abal.

\section{Kesimpulan}

Dalam upaya penerapan kehadiran dikelas yang efektif saat proses pembelajaran (learning process) dalampembahasan kali ini di jurnal ini diberikan beberapa terobosan dan solusi yang dianjurkan untuk dilaksanakan diantaranya sebagai berikut ini: a) madrasah mempunyai system pengendali kehadiran guru yang dijalankan secara proporsional, (b) setiap kali ada meeting dengan guru maka perlu diinfokan tentang frekuensi dan fluktuasi kehadiran guru mulai yang tertinggi hingga yang paling rendah. Selain itu juga perlu diimplementasikan system reward dan punishment untuk meningkatkan kedisiplinn guru dalam kehadiran teaching activity dikelas. (c) pada awal permulaan semester madrasah yang diwakili kepala madrasah membuat MoU bersama guru tentang kode etik techers descipline (d) menajdikan disiplin sebagai bentuk keteladanan dalam aktifitas sehari hari mulai dari headmaster madrasah hingga staff madrasah (e) memberikan obligasi guru untuk aktif mencatat buku absensi yang telah disediakan di dalam kelas jika aktiftas nya berupa luring, dan aktif mengisi e-learning madrasah jika aktifitas madrasah berjalan secaran daring/online, (f) mempersempit ruang gerak guru untuk bisa izin keluar dari kelas terlbih dahulu sebelum bel tanda berakhir jam pelajaran.

\section{Ucapan Terima Kasih}

[]. 


\section{Referensi}

Bennell, P., \& Akyeampong, K. (2007). Teacher Motivation in Sub-Saharan Africa and South Asia. London: DFID.

Dannur, M. (2017). Teori Adult Learning, Ekspriental Learning Cycle dan Perubahan Performance Individu Dalam Pendidikan dan Pelatihan. Fikrotuna, 5(1).

Ejere, E. I. (2010). Absence from Work: A Study of Teacher Absenteeism. International Journal of Business and Management, 5(9).

Fauzan, F. (2019). Peran Agama Dalam Pembentukan Karakter Pada Lembaga Pendidikan. Fikrotuna, 9(1).

Hasibun, S. M. (2015). Manajemen Sumber Daya Manusia. Edisi Revisi Cetakan

Ibrahim, B. (2004). Peningkatan Profesionalisme Guru SD. Jakarta: Bumi Aksara.

Mangkunegara, A. P. (2013). Manajemen Sumber Daya Manusia Perusahaan. Bandung: Remaja Rosdakarya.

Miller, R. (2012). Teacher absence as a leading indicator of student achievement. Center for American Progress.

Nugroho, B. (2006). Reward dan Punishment. Bulletin CiptaKarya

Purwanto, J. (2017). Upaya Meningkatkan Disiplin Guru Dalam Kehadiran Mengajar Di Kelas Melalui Reward And Punishment. Jurnal Bidang Pendidikan Dasar (JBPD), 1(2).

Ridho, A. (2017). Meningkatkan Mutu Manajemen Madrasah. Fikrotuna, 6(2)

Sinungang, M. (2008). Produktifitas Apa dan Bagaimana. Jakarta: Bumi Aksara.

Syaikhu, A., \& Daniel, S. (2004). Ketika Guru Absen: Kemana Mereka dan Bagaimana Murid? (Laporan Penelitian). Jakarta, Lembaga Penelitian SMERU 